September 2021

\title{
Tourism and life quality perceptions of local people: A comparative research in thermal tourism destinations
}

\author{
Ahmet Cetin \\ Pamukkale University, cetina@pau.edu.tr \\ Esra Katircioglu \\ Kütahya Dumlupınar University, esra.yilmaz@dpu.edu.tr \\ Mehmet Boyraz \\ Afyon Kocatepe University, mboyraz@aku.edu.tr \\ Hülya Mutlu \\ Afyon Kocatepe University, hulyamutlu@gmail.com \\ Hasan Huseyin Soybali \\ Afyon Kocatepe University, hsoybali@aku.edu.tr
}

Follow this and additional works at: https://digitalcommons.usf.edu/jometr

Part of the Hospitality Administration and Management Commons, and the Marketing Commons

\section{Recommended Citation}

Cetin, A., Katircioglu, E., Boyraz, M., Mutlu, H., \& Soybali, H. H. (2021). Tourism and life quality perceptions of local people: A comparative research in thermal tourism destinations. Journal of Mediterranean Tourism Research, 1(1), 53-69. https://www.doi.org/10.5038/2770-7555.1.1.1005

Corresponding Author

Ahmet Çetin, Pamukkale University, Denizli Vocational School of Social Sciences, 20160 Kınıklı / Denizli / Turkey

Revisions

Submission date: September 15, 2021; 1st Revision: September 26, 2021; Acceptance: September. 29,2021 


\title{
Tourism and Life Quality Perceptions of Local People: A Comparative Research in Thermal Tourism Destinations
}

\author{
Ahmet Çetin ${ }^{1}$, Esra Katırcıoğlu², Mehmet Boyraz ${ }^{3}$, Hülya Mutlư , \\ and H. Hüseyin Soybal1 ${ }^{5}$ \\ Denizli Vocational School of Social Sciences \\ Pamukkale University \\ ${ }^{1}$ cetina @ pau.edu.tr \\ Vocational School of Simav \\ Kütahya Dumlupınar University \\ 2esra.yilmaz@dpu.edu.tr \\ Tourism Faculty \\ Afyon Kocatepe University \\ ${ }^{3}$ mboyraz@aku.edu.tr \\ 5hsoybali@aku.edu.tr \\ Vocational School of Emirdağ \\ Afyon Kocatepe University \\ ${ }^{4}$ hulyamutlu@gmail.com
}

\begin{abstract}
The purpose of the research is to reveal locals' perceptions and attitudes toward tourism development in thermal tourism destinations, as well as to determine whether these perceptions and attitudes differ depending on the socio-demographic characteristics of the participants. Accordingly, seven hypotheses were constructed. The population of the research is formed by residents living in thermal tourism cities in the North Aegean Region. The study was designed as quantitative, and the survey method was used as the data collection tool. Using the convenience sampling method, 827 questionnaires in total were collected from locals living in Afyonkarahisar, Denizli, and Kütahya between the 1st and 30th of December 2018. To analyze the data, confirmatory factor analysis, descriptive statistics, frequency analysis, reliability analysis, t-test, ANOVA, and correlation analysis were used. According to the results obtained, it was determined that more than half of the participants interacted with tourists often or very often. In the research, it was also found that there were partial significant differences in terms of gender, age, marital status, education, monthly income and duration of residence in the city and level of interaction with tourists.
\end{abstract}

Keywords: local people, thermal tourism, destination, tourism perception, attitude 


\section{Introduction}

As globalization accelerates in the first quarter of the twenty-first century, the income generated by tourism mobility is known to have a determinant quality in the economic development of countries. Developing countries, in particular, rely far more on the capital generated by tourism mobility, while simultaneously creating or diversifying touristic products without prior planning. The most important factor contributing to this impulsive attitude is the desire for a greater share of the tourism which results from viewing the tourism phenomenon solely from an economic perspective (Theuns, 2002). One of the reasons for the perception of tourism as merely an economic event is that the first studies on tourism were conducted by economists (Jafari, 2003). Tourism studies have long been studied in economics and expressed entirely through economic indicators (Dwyer et al., 2006), reinforcing the notion that tourism is merely an economic event. On the other hand, in addition to the economic dimension of tourism over time, the sociological, psychological, cultural, environmental, and political dimensions of tourism have been identified; as a result, there has been a shift in the axis of tourism research and in accordance with all of the phenomenon's dimensions (Graburn \& Jafari, 1991). As a result, various approaches to the development of tourism destinations have begun to emerge and be adopted (Tosun, 2000). The community-based approach is one of these approaches supporting the idea that local people should collaborate with policymakers as stakeholders in the development of tourism. Since the legislators cannot anticipate the views and interests of the residents, the community-based approach encourages residents to participate in the tourism destination's planning and growth (Murphy, 1985 as cited in Malek, \& Costa, 2015).

It is critical to value the opinions and thoughts of the local people, particularly in the planning and development of touristic destinations. Jurowski et al., (1997) claim that having the support of local people is crucial for sustainable tourism development and successful tourism practices. Furthermore, the public's participation in tourism mobility aims to reduce the potential social and cultural harms that may result from tourist-local people interaction. While tourism is regarded as an important financial resource in the development of communities, it may also appear as a contentious threat with the potential to destroy destinations' social, cultural, and environmental elements (Murphy, 1983; Tanrisevdi et al., 2021). Accordingly, the main aim of this study is to reveal the differences in tourism perception and support levels among three cities located in Northern Aegean region. Within the framework of the study, cities as Afyonkarahisar, Denizli, and Kütahya have been chosen in order to conduct the research as these cities are given priority to develop thermal tourism within Turkish Tourism Strategy 2023.

\section{Literature Review}

It is generally accepted that in regions where tourism develops, there are economic benefits such as increased employment due to the creation of new branches of activity for the local population, tax exemption, and socioeconomic development. Tourism also brings advantages that increase the quality of life such as more recreational activities, festival organizations, the increase in the number of restaurants and natural and cultural attractions. However, there may be negative consequences for quality of life, such as population expansion, traffic and parking issues, and an increase in crime rates. (Andereck et al., 2005; Ap \& Crompton, 1993; Arıca, 2020; Jafaar et al., 2015; Rasoolimanesh et al., 2015). Getz (1987) stated that planning is a process that enables to explore the potential contributions of tourism to human welfare and environmental quality. Correct and 
meticulous planning not only prevents negative tourism consequences, but also boosts customer pleasure and economic advantage (Timothy, 1999). Moving from the idea that business or government institutions cannot operate independently and in isolation from other businesses and institutions, tourism planning is a process that should be designed as an interactive system model that includes social and economic development (Gunn, 1988). Especially after World War II, the main purpose of destination planning and development in tourism mobility, which countries applied to reduce their economic problems and to revive the economy, was to gain economic benefits. For this reason, the socio-cultural, environmental, and political disadvantages of tourism were ignored (Murphy, 1983). However, over the years, it has become clear that the local people living in developed or expected to develop tourism destinations have to cope with some difficulties, and as a result, destination planning and development activities have appeared to be too delicate to conduct solely on the basis of the economic dimension of the phenomenon (Andereck \& Vogt, 2000; Arıca \& Ukav, 2020; Cengiz \& Kırkbir, 2007; Ko \& Stewart, 2002; Özmen, 2007; Tanrisevdi et al., 2021).

The community-based approach is one of the approaches used in the pre-planning process for destinations where tourism is predicted to grow. The participatory approach was first used to describe the community-based approach, which was later renamed as "community approach" and "community-based approach" throughout time. The negative consequences of tourism on the destination and local people should also be foreseen, according to the community-based approach. For this reason, local people should be involved in the planning process (Prentice, 1993). The essential goal of this approach is to predetermine the possible negative effects of tourism on the environment and local people and to carry out a planning that minimizes these effects. Therefore, informing the public in advance and seeking their opinions are among the primary objectives in touristic destinations (Keogh, 1990). By the way, the local people should be open to the tourist activity and tourists in the region so that tourists can be attracted to the region and leave the region satisfied (Davis et al., 1988).

There are various studies on determining the tourism perception of the local people in the literature. In their study, Perdue et al., (1990) focused on determining the local people's thoughts and ideas on the effects of tourism and developed a model that reveals the relationship between local people's support for possible tourism development and the effects of tourism perceived by local people. Keogh (1990) stressed that in the Cap-Pele region of Canada, the residents were not sufficiently informed about the planning processes in the destinations where tourism was to be developed, and in this regard, paying special attention to the thoughts of the residents for tourism planning that would be carried out emerged as extremely important in solving future problems that may occur in the region.

Prentice (1993) discovered in a study conducted in the North Pennines countryside of England that local people supported tourism development, particularly for the sake of its potential for job creation, but they did not support the creation of resources for tourism development. Within the scope of the study to determine the tourism perception of the local people in Turkey, Ürgüp, Fiji Nadi and Florida, USA, Tosun (2002) determined that the tourism perception has a five-factor structure. Choi and Sirakaya (2005), conducted their study in the USA Texas region and by suggesting a "sustainable community-based approach" to be adopted in the creation of tourism destinations, pointed at the paradigm shifts in the community-based tourism approach. Researchers have also come up with a seven-factor scale to measure the tourism perception of the local people 
residing in the regions where tourism is planned to be developed. The study, in which Kim et al., (2013) sought answers to the question of how tourism affects local people's life quality socially, economically, culturally, and environmentally, revealed that as a consequence of the increase in the perceptions of the local people about tourism, people's life satisfaction for various living conditions also increased. They concluded that this effect had an impact on the whole life satisfaction, as well. Taking this conclusion to the core of their argument, they emphasized the necessity for the tourism planners to make their plans by taking the tourism perception of the local people into account. Akova (2006) conducted a two-stage study in Bursa Cumalıkızik village. In this study, which compared the data obtained in 2001 with those in 2003 to determine the perceptions and attitudes of the local people towards the development of tourism, it was concluded that the tourism perception of the local people changed in a positive way within two-year period. Sandal and Karademir (2016) showed that local people in Kahramanmaraş had a positive attitude for the development of tourism, Vatan and Zengin (2015) stated that while the local people in Bilecik found the economic returns of tourism positive, they also expressed its negative effects on the environment. In their study, Duran and Özkul (2012) drew the conclusion that the people living in Akçakoca referred to the benefit to be gained from tourism as more than the price to be paid and they were willing to take active place to support tourism. Keskin and Çontu (2011) claimed that although people in Mustafapaşa district had an overall positive attitude towards tourism, they were also concerned with the negative effects it would have on their social life. Bertan (2010) determined that the local people have both positive and negative views on the socio-cultural effects of tourism and concluded that having a positive opinion plays a significant role in supporting tourism, whereas a negative opinion does not make a worthy difference.

Çalışkan and Tütüncü (2008) evaluated the tourism perceptions of the people in Kuşadası in terms of environment, economy, and socio-cultural aspects and revealed that people became dependent on tourism economically and the environment was destroyed accordingly, yet the tourism did not have a negative effect socially. In their study, Tayfun and Kiliçlar (2004) claimed that it is of great importance for people living in Alanya and Gazipaşa to develop tourism and make more tourism investments. In the light of all of these studies, determining local people's tourism perceptions is regarded as critical for creating tourism mobility in a specific region and developing the region's tourism. Local people's support for the development of tourism in their region might be seen as an indicator that they have adopted the idea that tourism is a phenomenon that affects them and the society they live in. When the tourism perception is determined as positive, it is possible to claim that the touristic activity planned to be developed in that region will be supported by the local people, and if it turns out to be negative, local people will not support the steps to be taken towards the development of tourism (Kim et al., 2013). What affects local people's support for the tourism mobility in a destination is their economic, social, or cultural benefit from the tourism activities developed in that region. Depending on the increase in the satisfaction level of the local people regarding the tourism activity, Ekici and Çizel (2014) stated that the support given by the people for the development of tourism in that region also increased. However, in the study conducted by Çiçek and Sarı (2018) in Vize, Taraklı, Yenipazar, Gökçeada, Seferihisar and Akyaka in Turkey, no relationship was found between the benefits of local people from tourism and their attitudes and perceptions towards tourism. Researchers linked that with the newly developing tourism activity in the region and interpreted the research results through this data. Having reached a similar conclusion, Ünlüönen and Özekici (2017) revealed that the local people remained neutral regarding the positive or negative cultural and environmental effects of tourism, and they had a positive perception towards its negative economic effects. In this context, the researchers stated 
that examining the information sources of the local people on tourism would be effective in explaining such a result.

Another issue concerning the tourism perception of the local people is to maintain the sustainability of tourism. The residents' support for tourism in a region develops accordingly with the sustainability of the tourism activity in that region. When the local people do not support tourism activity, it becomes extremely difficult to achieve a sustainable development in tourism (Karakaş \& Şengün, 2016). While environmental, social, and economic development constitutes the core of the concept of sustainability; establishing a balanced relationship between these factors is the basis of sustainability (Ar1ca, 2020; Pelit et al., 2015). Causing paradigmatic shifts in the research, the concept of sustainability has also been adopted as a sustainability approach, and the core of the concept is used as a term arising from the economic development theory and environmentalism (Hardy et al., 2002). Especially in the development of tourism destinations, each place or destination has peculiar characteristics in terms of their unique, natural, and organizational form, and in this context, from the size of the lakes to the formation of coastlines, transportation networks, schools, hospitals, shopping centers, mountains, hotels and recreational facilities, water, agricultural resources and to local people, all seem to form a complex system (Farrell \& TwiningWard, 2005). Therefore, adaptation to the characteristics of a particular place and the desires and value judgments of the local people is it is thought to be critical in adopting a sustainable development model.

In this context, discovering the views and thoughts of the local people in the study, particularly revealing the perspective of the local people on tourism in thermal destinations, has much significance in terms of the sustainability of the tourism destinations developed or planned to be developed in the regions where the study is conducted.

\section{Methods}

The aim of this study is to find out the perceptions and attitudes of the local people living in the thermal tourism destinations towards the development of tourism, as well as to reveal the differences between the tourism perceptions, support and the quality-of-life perceptions of local people living in the thermal destinations within the borders of three provinces in the same geographical region. It is also aimed to determine the relationships between the factors that emerged in the research. In the present study, which was intended to be quantitative, survey technique was used as the data collection tool.

\section{Data Collection}

In the process of forming the questionnaire, the scales used in the studies of Akova, 2006; Bayat, 2010; Bertan, 2010; Caliskan and Tütüncü, 2008; Epley and Menon, 2008; Gürsoy and Rutherford, 2004; Kim et al., 2013; McGehee and Andereck, 2004; Rahtz and Sirgy, 2000; Suess et al., 2018 were benefited and the items were adapted to thermal tourism, and the research questionnaire was finalized in accordance with the research objectives. The questionnaire form consists of three parts. The first part includes six open-ended questions to reveal the demographic and general characteristics of the participants. In the second part 28 items which consisting of four factors were used to determine the general tourism perception and tourism support of the local people. In the third part, 8 items were used for measuring the perception of quality of life. 5-point Likert type 
rating was preferred in the scale $(1=$ Strongly Disagree, $2=$ Disagree, $3=$ Neutral, $4=$ Agree, $5=$ Strongly Agree).

The tourism perception and support scale included 28 items when it was first designed, but it was reduced to 25 after confirmatory factor analysis. In the scale designation process, researchers used different scales from several studies. Table 1 lists the studies that the scale's items were generated from.

Table 1. The Latest Version of Items and Source References Used in the Scale

\section{Tourism Perception and Support Item \\ The development of tourism creates more job opportunities for this community/region. \\ The development of tourism allows more investment in this region.}

Tourism increases and diversifies the cultural activities of local people.

Tourism has significantly raised our standard of living..

The development of tourism in the region will also benefit my / my family's business.

Tourism provides more infrastructure and facilities that benefit the public, such as roads, health care facilities, and recreational areas, etc.

Tourism also allows women to participate in the business world.

Parks, promenades and entertainment places built for tourism purposes allow local people to spend quality time.

Tourism enhances the image of local culture and enables residents to preserve their culture.

The development of the touristic superstructure enables the locals to benefit more from hotels, pools and other touristic structures.

Tourism has a positive impact on the dissemination of our culture and values.

The arrival of people from different cultures to the region contributes to mutual understanding and tolerance.

I believe that tourism should be actively promoted in my community/region.

I support the development of tourism in the region.

I want to participate in activities that foster the development of tourism.

Tourism, in my opinion, is an important component of regional and societal development.

I voluntarily participate in and contribute to activities related to the promotion of this region.

Locals suffer as a result of living in a tourist hotspot.

The influx of tourists causes a decline in social morals and moral ideals in the region.

Tourism causes traffic jams, crowds, noise and pollution.

\section{Reference}

Akova, (2006); Bayat, (2010); Çalışkan and Tütüncü, (2008); Gursoy and Rutherford, (2004); Kim et al., (2013); McGehee and Andereck, (2004)

Bayat, (2010); Çalışkan and Tütüncü, (2008); Gursoy and Rutherford, (2004); McGehee and Andereck, (2004); Kim et al., (2013)

Bayat, (2010): Bertan, (2010); Kim et al., (2013);

McGehee and Andereck, (2004)

Akova, (2006); Bayat, (2010); Kim et al., (2013);

McGehee and Andereck, (2004)

Gursoy and Rutherford, (2004)

Bayat, (2010); Gursoy and Rutherford, (2004); Kim et al., (2013); McGehee and Andereck, (2004)

Çalışkan and Tütüncü, (2008)

Akova, (2006); Bertan, (2010); Gursoy and Rutherford, (2004); Kim et al., (2013); McGehee and Andereck, (2004)

Akova, (2006); Bayat, (2010); Bertan, (2010); Gursoy and Rutherford, (2004); McGehee and Andereck, (2004)

Bayat, (2010); Gursoy and Rutherford, (2004);

McGehee and Andereck, (2004)

Akova, (2006); Bayat, (2010); McGehee and Andereck, (2004) Bertan, (2010); Kim et al., (2013)

Akova, (2006); Bayat, (2010); McGehee and Andereck, (2004) Bertan, (2010); Kim et al., (2013) McGehee and Andereck, (2004)

McGehee and Andereck, (2004)

McGehee and Andereck, (2004)

McGehee and Andereck, (2004)

McGehee and Andereck, (2004)

Bertan, (2010); McGehee and Andereck, (2004)

Akova, (2006); Bertan, (2010); Çalışkan and Tütüncü, (2008); Gursoy and Rutherford, (2004); McGehee and Andereck, (2004)

Akova, (2006); Çalışkan and Tütüncü, (2008); Gursoy and Rutherford, (2004); Kim et al., (2013); McGehee and Andereck, (2004) 
The construction of hotels and other tourist facilities destroys the natural environment.

The development of tourism causes the cost of living.

Due to the development of tourism, a large number of unqualified people migrate to the region.

Tourism causes an increase in the crime rate in the society.

Behaviors of local people change badly by being affected by tourists.

\section{Item on Perception of Quality of Life}

I am happy to live in this region.

This region is an ideal place for living.

This region is an ideal place for raising children.

The educational opportunities in this region are adequate.

Health facilities in this region are adequate.

In this region, prices for food and other necessities are generally reasonable.

People are helpful in this region.

Cultural and social activities are adequate in this region.
Akova, (2006); Gursoy and Rutherford, (2004); Kim et al., (2013)

Akova, (2006); Bayat, (2010); Çalışkan and Tütüncü, (2008); Gursoy and Rutherford, (2004); McGehee and Andereck, (2004)

Gökmen, (2018)

Akova, (2006); Bertan, (2010); Çalışkan and Tütüncü, (2008); Gursoy and Rutherford, (2004); McGehee and Andereck, (2004)

Akova, (2006); Bertan, (2010); Gursoy and

Rutherford, (2004); McGehee and Andereck, (2004)

Çalışkan and Tütüncü, (2008); Kim et al., (2013);

Suess et al., (2018)

Kim et al., (2013)

Epley and Menon, (2008)

Epley and Menon, (2008)

Rahtz and Sirgy (2000); Kim et al., (2013)

Kim et al., (2013)

Kim et al., (2013)

Epley and Menon, (2008); Kim et al., (2013)

\section{Data Source}

The population of the research was limited to the local people living in thermal tourism cities (Afyonkarahisar, Denizli, and Kütahya) in the North Aegean Region. The assumption that the provinces are adjacent to each other, the richness of underground resources, and the local people of the region have similar characteristics is why the research application area was chosen as these three provinces.

The survey questions were asked to the local people determined with convenience sampling method simultaneously in the city center and Sand1klı district of Afyonkarahisar, Pamukkale district of Denizli, and Simav district of Kütahya between the 1 and 30 December in 2018.

Within the scope of the study, face-to-face interviews were conducted for the questionnaires. The participants in the study were supposed to be roughly 18 years old or older, to have lived in the relevant location for at least three years, and to be familiar with and understand the region's tourism. In this sense, in this specific time period, a total of 827 fully filled questionnaires were obtained; 277 of them were from Afyonkarahisar, 300 from Denizli, and 250 from Kütahya.

\section{Findings}

In this section, among the thermal tourism destinations, people living in Afyonkarahisar, Denizli, and Kütahya provinces were chosen and their positive economic perceptions of tourism, positive social perceptions, negative perceptions, support for tourism and quality of life perceptions were determined. Also, the findings related to the differences according to the variables, the findings related to the relationships between the variables and the discussions were included. 
Table 2. The Demographic Characteristics of the Participants

\begin{tabular}{|c|c|c|c|c|c|c|c|c|c|}
\hline \multirow{2}{*}{ Characteristics } & \multirow{2}{*}{ Variable } & \multicolumn{2}{|c|}{ Afyonkarahisar } & \multicolumn{2}{|c|}{ Denizli } & \multicolumn{2}{|c|}{ Kütahya } & \multicolumn{2}{|c|}{ Total } \\
\hline & & $n$ & $\%$ & $n$ & $\%$ & $n$ & $\%$ & $n$ & $\%$ \\
\hline \multirow{2}{*}{ Gender } & Female & 110 & 39,7 & 108 & 36,0 & 85 & 34,0 & 303 & 36,6 \\
\hline & Male & 167 & 60,3 & 192 & 64,0 & 165 & 66,0 & 524 & 63,4 \\
\hline \multirow{5}{*}{ Age } & $18-27$ & $\begin{array}{l}43 \\
56\end{array}$ & 15,5 & 77 & 25,7 & 46 & 18,4 & 166 & 20,1 \\
\hline & $28-37$ & 56 & 20,2 & 98 & 32,7 & 74 & 29,6 & 228 & 27,6 \\
\hline & $38-47$ & 133 & 48,0 & 78 & 26,0 & 69 & 27,6 & 280 & 33,9 \\
\hline & $48-57$ & 31 & 11,2 & 31 & 10,3 & 51 & 20,4 & 113 & 13,7 \\
\hline & 58 and above & 14 & 5,1 & 16 & 5,3 & 10 & 4,0 & 40 & 4,8 \\
\hline \multirow{3}{*}{ Marital Status } & Single & 52 & 18,8 & 99 & 33,0 & 55 & 22,0 & 206 & 24,9 \\
\hline & Married with kids & 215 & 77,6 & 193 & 64,3 & 192 & 76,8 & 600 & 72,5 \\
\hline & Widow & 10 & 3,6 & 8 & 2,7 & 3 & 1,2 & 21 & 2,5 \\
\hline \multirow{6}{*}{ Education } & Primary Education & 68 & 24,5 & 36 & 12,0 & 14 & 5,6 & 118 & 14,3 \\
\hline & Junior High school & 55 & 19,9 & 63 & 21,0 & 20 & 8,0 & 138 & 16,7 \\
\hline & High School & 78 & 28,2 & 104 & 34,7 & 69 & 27,6 & 251 & 30,4 \\
\hline & Associate & 19 & 6,9 & 40 & 13,3 & 51 & 20,4 & 110 & 13,3 \\
\hline & Undergraduate & 47 & 17,0 & 48 & 16,0 & 75 & 30,0 & 170 & 20,6 \\
\hline & Post-graduate & 10 & 3,6 & 9 & 3,0 & 21 & 8,4 & 40 & 4,8 \\
\hline \multirow{6}{*}{$\begin{array}{l}\text { Monthly } \\
\text { Income }\end{array}$} & Less than min wage & 75 & 27,1 & 35 & 11,7 & 27 & 10,8 & 137 & 16,6 \\
\hline & Minimum wage & 58 & 20,9 & 55 & 18,3 & 43 & 17,2 & 156 & 18,9 \\
\hline & $2000-3000 \mathrm{TL}$ & 69 & 24,9 & 112 & 37,3 & 55 & 22,0 & 236 & 28,5 \\
\hline & $3001-4000 \mathrm{TL}$ & 35 & 12,6 & 51 & 17,0 & 63 & 25,2 & 149 & 18,0 \\
\hline & $4001-5000 \mathrm{TL}$ & 18 & 6,5 & 16 & 5,3 & 32 & 12,8 & 66 & 8,0 \\
\hline & 5001 TL or more & 22 & 7,9 & 31 & 10,3 & 30 & 12,0 & 83 & 10,0 \\
\hline \multirow{5}{*}{$\begin{array}{l}\text { Duration of } \\
\text { residence in } \\
\text { the city }\end{array}$} & Between 3-5 vears & 18 & 6,5 & 46 & 15,3 & 22 & 8,8 & 86 & 10,4 \\
\hline & Between 6-10 years & 20 & 7,2 & 36 & 12,0 & 27 & 10,8 & 83 & 10,0 \\
\hline & Between 11-15 years & 14 & 5,1 & 19 & 6,3 & 26 & 10,4 & 59 & 7,1 \\
\hline & Between 16-20 years & 28 & 10,1 & 36 & 12,0 & 23 & 9,2 & 87 & 10,5 \\
\hline & 21 or more & 197 & 71,1 & 163 & 54,3 & 152 & 60,8 & 512 & 61,9 \\
\hline \multirow{5}{*}{$\begin{array}{l}\text { The Frequency } \\
\text { of Interaction } \\
\text { with Tourists }\end{array}$} & & 11 & 4,0 & 70 & 23,3 & 4 & 1,6 & 85 & 10,3 \\
\hline & Rarely & 16 & 5,8 & 86 & 28,7 & 17 & 6,8 & 119 & 14,14 \\
\hline & Sometimes & 44 & 15,9 & 93 & 31,0 & 70 & 28,0 & 207 & 25,0 \\
\hline & Often & 62 & 22,4 & 30 & 10,0 & 80 & 32,0 & 172 & 20,8 \\
\hline & Very often & 144 & 52,0 & 21 & 7,0 & 89 & 31,6 & 244 & 29,5 \\
\hline
\end{tabular}

The descriptive statistics of the local people in the thermal tourism destinations participating in the research were given in Table 2. In this context, gender, age, marital status, education, monthly income, life expectancy in the province and the level of interaction with tourists were considered as socio-demographic variables. The majority (63.4\%) of the 827 people participating in the research were men, and the remaining $36.6 \%$ were women, and the distribution by gender based on provinces was also in the same range. $47.6 \%$ of the participants were determined to be in the 18-37 young age group, $47.6 \%$ of them in the 38-57 middle age group, and the rest in the 58-yearold and older. In terms of marital status, one out of every four people in Kütahya, one out of every three people in Denizli, and one out of every five people in Afyonkarahisar were single. 38.7\% of the individuals completed at least an undergraduate degree, with Kütahya having the highest rate with $58.8 \%$. The participants were determined to have a moderate monthly income and there was a balanced distribution between the groups; the individuals with the lowest income group on the basis of provinces lived in Afyonkarahisar, while the highest income group lived in Kütahya. 
When the distribution of the participants' lifespan was examined in terms of destinations, it was determined that approximately $90 \%$ of them had lived within the borders of the relevant province for at least ten years and $62 \%$ of them for at least 20 years, and these rates were mostly valid for the local people in Afyonkarahisar. Finally, 50.3\% of the local people interact with tourists frequently or very frequently as a whole, and when the provinces were evaluated one by one, this rate was the highest in Afyonkarahisar with $74.4 \%$ and was followed by Kütahya with $63.3 \%$.

\section{Findings Related to Validity Analyzes of Tourism Perception and Support Scale}

Table 3 shows the results of the scales' reliability analysis. Using Cronbach's Alpha values, it is possible to state that the reliability levels of the scales used in the research are satisfactory (Büyüköztürk, 2016).

Table 3. Reliability Levels of the Scales

\begin{tabular}{|c|c|c|c|c|c|c|c|c|}
\hline \multirow[b]{2}{*}{ Scale } & \multicolumn{2}{|c|}{ Afyonkarahisar } & \multicolumn{2}{|c|}{ Denizli } & \multicolumn{2}{|c|}{ Kütahya } & \multicolumn{2}{|c|}{ All three cities } \\
\hline & $\begin{array}{c}\text { Cronbach's } \\
\text { Alpha }\end{array}$ & $\begin{array}{l}\text { Number } \\
\text { of Items }\end{array}$ & $\begin{array}{c}\text { Cronbach's } \\
\text { Alpha }\end{array}$ & $\begin{array}{l}\text { Number } \\
\text { of Items }\end{array}$ & $\begin{array}{c}\text { Cronbach's } \\
\text { Alpha }\end{array}$ & $\begin{array}{l}\text { Number } \\
\text { of Items }\end{array}$ & $\begin{array}{c}\text { Cronbach's } \\
\text { Alpha }\end{array}$ & $\begin{array}{l}\text { Number } \\
\text { of Items }\end{array}$ \\
\hline $\begin{array}{l}\text { Tourism } \\
\text { Perception } \\
\text { and Support }\end{array}$ &, 897 & 25 &, 837 & 25 &, 773 & 25 &, 820 & 25 \\
\hline $\begin{array}{l}\text { Quality of } \\
\text { Life }\end{array}$ & ,724 & 8 & ,838 & 8 & ,795 & 8 & ,805 & 8 \\
\hline
\end{tabular}

The kurtosis and skewness values of the factors were analyzed to see if they were suitable for further analysis, and the values were found to be between -1.5 and +1.5 . These values are acceptable because they are within the normal distribution range (George \& Mallery, 2010).

Confirmatory factor analysis was performed on the scale shown in Table 1. Chi-Square Goodness, GFI (Goodness of Fit Index), RMSEA (Root Mean Square Error of Approximation), CFI (Comparative Fit Index), NFI (Normed Fit Index), RFI (Relative Fit Index), IFI (In-cremental Fit Index) and AGFI (Adjusted Goodness of Fit Index) were examined by confirmatory factor analysis. In literature, .90 is asserted as an acceptable goodness of fit value for GFI, CFI, NFI, RFI, IFI, and AGFI indexes. Besides, .08 is perfect fit value for RMSEA (Bentler, 1980; Bentler \& Bonett, 1980; Browne \& Cudeck, 1993). Furthermore, CMIN/DF value less than 5 indicates that the fit is adequate (Marsh \& Hocevar, 1985).

In modifying thermal tourism perception and support scale, fit indices of the four-factor scale were tested and the fit indices were found to be significant. The confirmatory factor analysis results are shown in Table 4.

Table 4. Fit Indices

\begin{tabular}{ccccccccc}
\hline CMIN/DF & $\boldsymbol{p}$ & GFI & RMSEA & CFI & NFI & RFI & IFI & AGFI \\
\hline 4,199 &, 000 &, 899 &, 062 &, 933 &, 914 &, 903 &, 933 &, 876 \\
\hline Note. $N=837$ & & & & & & & &
\end{tabular}

When the values obtained from the confirmatory factor analysis fit indices are examined, it is revealed that the scale is acceptable. 3D model of confirmatory factor analysis is shown in Figure 1. As observed in Figure 1, the correlation coefficients for the items vary between 0.57 and 0.85 . 
The analysis yielded a Chi-Square (X2) value of 1112,762, and the sd (DF) value is calculated by dividing the 265 values, yielding 4.199. This value less than 5 indicates that the fit is adequate.

Figure 1. 3D Model of Confirmatory Factor Analysis

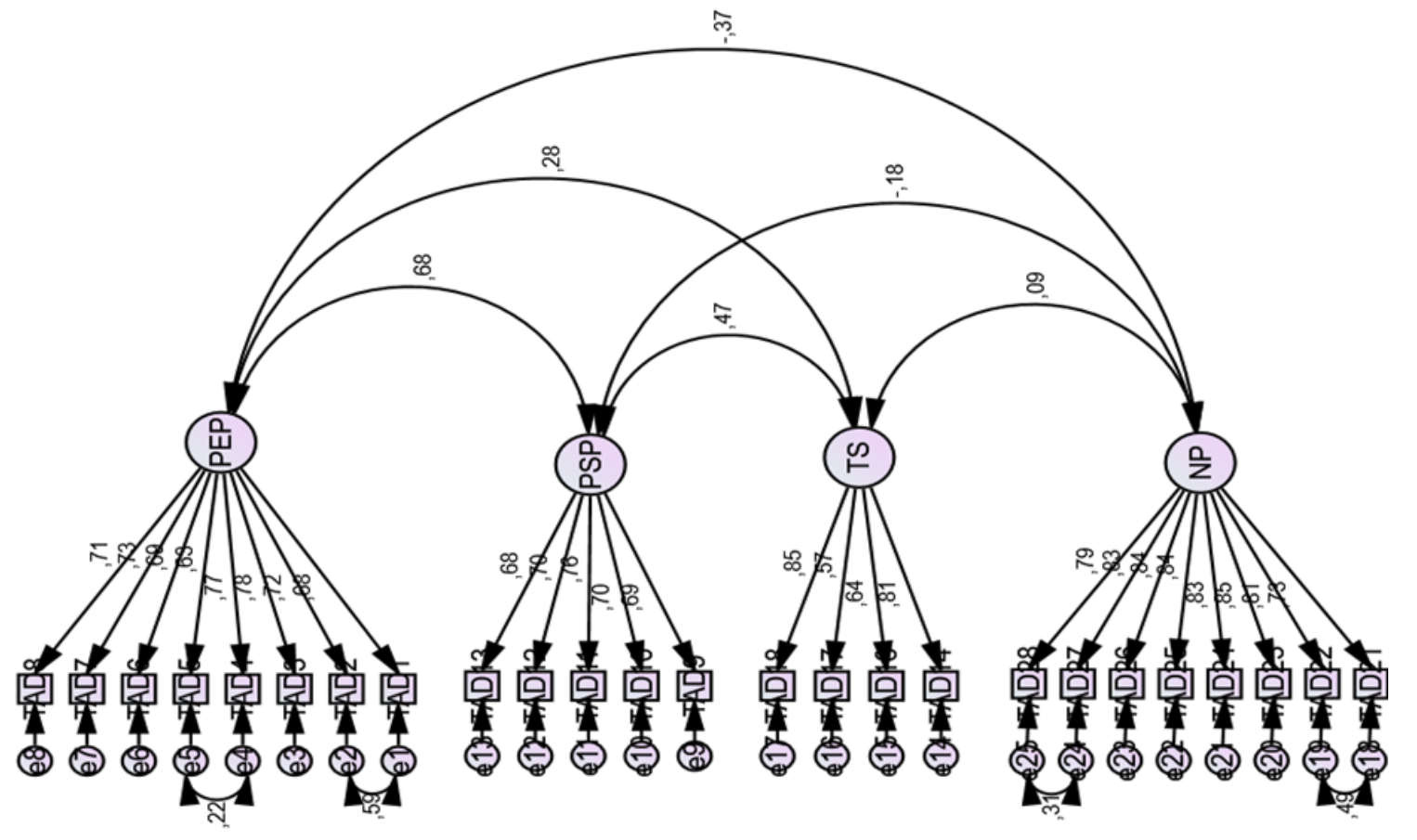

According to the confirmatory factor analysis, it was observed that modifications should be made between the errors of items 1 and 2, 4 and 5,21 and 22, and 27 and 28. The factor loads of tourism perception and support scale range from 0.63 and 0.78 for the positive economic perception (PEP), between 0.68 and 0.76 for the positive social perception (PSP), between 0.57 and 0.85 for the tourism support (TS), and it varies between 0.73 and 0.85 for negative perception (NP).

\section{Findings on the Relationship Analyzes Between Variables}

By examining the obtained findings of the results, ANOVA analyses were used to evaluate the attitudes of the individuals residing in the listed provinces, as well as the differences between the groups. Correlation analysis was carried out to determine the relationships between the dimensions of the perceptions of the local people living in the three provinces and, the findings obtained from the analyzes are presented below.

ANOVA analyzes were applied to determine whether the provinces differ in terms of quality of life, positive economic perception, positive social perception, tourism support and negative perception factors, in terms of demographic variables (educational status, occupation, age and income level) and frequency of interaction with tourists. In the study, the differences in factors according to demographic variables in three of the provinces are given in Table 5. While applying ANOVA analysis, Scheffe analysis was used under the assumption of equal variance and Tamhane analysis results were evaluated under the assumption of unequal variance, as stated by Coşkun et al., (2017). 
Table 5. The Differences in Terms of Demographic Variables in Provinces

\begin{tabular}{|c|c|c|c|c|c|c|c|c|}
\hline \multicolumn{3}{|c|}{ Afyonkarahisar } & \multicolumn{3}{|c|}{ Denizli } & \multicolumn{3}{|c|}{ Kütahya } \\
\hline $\begin{array}{l}\text { Perception of } \\
\text { Life Quality }\end{array}$ & $\begin{array}{l}\text { Income } \\
\text { Education }\end{array}$ & $\begin{array}{l}, 046^{*} \\
, 020\end{array}$ & $\begin{array}{l}\text { Positive } \\
\text { Economic } \\
\text { Perception }\end{array}$ & Age & ,048 & $\begin{array}{l}\text { Perception of } \\
\text { Life Quality }\end{array}$ & $\begin{array}{l}\text { Duration of } \\
\text { residence }\end{array}$ &, $004 *$ \\
\hline $\begin{array}{l}\text { Positive } \\
\text { Social } \\
\text { Perception }\end{array}$ & $\begin{array}{l}\text { Education } \\
\text { Age }\end{array}$ & $\begin{array}{l}, 046^{*} \\
, 043^{*}\end{array}$ & $\begin{array}{l}\text { Negative } \\
\text { Perception }\end{array}$ & $\begin{array}{l}\text { Education } \\
\text { Duration } \\
\text { of } \\
\text { residence }\end{array}$ & $\begin{array}{l}, 030 \\
, 042\end{array}$ & $\begin{array}{l}\text { Negative } \\
\text { Perception }\end{array}$ & Education &, $039^{*}$ \\
\hline $\begin{array}{l}\text { Negative } \\
\text { Perception }\end{array}$ & $\begin{array}{l}\text { Education } \\
\text { Age } \\
\text { Interaction }\end{array}$ & $\begin{array}{l}, 037^{*} \\
, 032^{*} \\
, 025^{*}\end{array}$ & $\begin{array}{l}\text { Tourism } \\
\text { Support }\end{array}$ & Age & ,036 & $\begin{array}{l}\text { Tourism } \\
\text { Support }\end{array}$ & Income &, $038^{*}$ \\
\hline
\end{tabular}

Post Hoc tests were conducted regarding the perception of quality of life, positive social perception, and negative perception factors, which were found to be significantly different in the results of ANOVA tests of Afyonkarahisar. In terms of the education status, the distributions of the factors were found to be homogeneous with the exception of the tourism support factor. Since the number of samples in the groups was not equal in the educational status variable and the variances were homogeneously distributed, one of the Post Hoc tests, Scheffe analysis was performed. However, no significant difference between the groups in terms of education, according to the factors of perception of life quality, positive social perception and negative perception was found.

According to the obtained results, a difference in the positive social perception and negative perception factors in terms of age was observed. The variance distribution of the negative perception factor was not homogeneous, and Tamhane analysis results were examined for Levene $(p=0.004)$, but no significant difference was found among the groups. The variance distribution of positive social perception factor was homogenous and Scheffe analysis was performed but there was no significant difference between the groups. Although it was observed that there was a difference in the perception of quality-of-life factor between the groups according to the income level variable, there was no significant difference between the groups in the Post Hoc tests., When it is examined whether the negative perception factor differed according to the frequency of interaction with tourists, the post hoc tests were applied to get the details between the groups, and since it did not show a homogeneous distribution, Tamhane test was used. A significant difference was found between the group that sometimes interacted with tourists and the group that had no interaction $(p=0.021)$, whereas there was a higher mean for the ones that interacted $(M=4.363)$ than those who said they did not experience any interaction $(M=4,063)$. There was no significant difference based on education or age.

The analysis of Denizli province revealed the positive economic perception and tourism support factors had a significant difference in terms of age, and negative perception factor had a significant difference in terms of the education and duration of residence levels. Post Hoc tests, performed to see which groups had difference, and revealed that since there was no homogeneous distribution in the variances of this factor, Tamhane results were examined, but there was no significant difference between the groups within the education level.

In the analysis of Kütahya, even though the negative perception factor had a significant difference in terms of the education and tourism support factor had a significant difference in income level, Post Hoc analyzes gave no values indicating a significant difference between the groups. In the 
perception of life quality analysis of the people living in the region, a significant difference between the local population groups living 3-5 years, 11-15 years (.045) and over 21 years (.007) was determined in the Post Hoc tests. In the Post Hoc tests performed, the variable of interaction frequency with tourists differed between the groups in terms of the factor of perception of quality of life and this difference was found between those who interacted frequently and the group who sometimes interacted (.021). When compared, it was observed that the means of people who interacted with tourists frequently $(M=3,638)$ were higher than those who sometimes interacted $(M=3,032)$.

ANOVA test results, the means and standard deviations of the variables for each region have been given in Table 6.

Table 6. The Differences in Tourism Perception, Perception of Life Quality and Tourism Support by Provinces

\begin{tabular}{llllll}
\hline Item & Group & $\boldsymbol{M}$ & $\boldsymbol{S . D .}$ & $\boldsymbol{F}$ & $\boldsymbol{p}$ \\
\hline \multirow{3}{*}{ Positive Economic Perception } & Afyonkarahisar & 3,724 & 0,871 & & \\
& Denizli & 4,515 & 0,650 & 98,609 & \multirow{2}{*}{, $000^{*}$} \\
& Kütahya & 4,393 & 0,595 & & \\
\multirow{4}{*}{ Positive Social Perception } & Afyonkarahisar & 4,079 & 0,753 & & \\
& Denizli & 4,462 & 0,630 & 20,001 &, $000^{*}$ \\
& Kütahya & 4,301 & 0,696 & & \\
\multirow{5}{*}{ Negative Perception } & Afyonkarahisar & 4,177 & 0,620 & & \\
& Denizli & 2,259 & 1,042 & 396,022 & \multirow{2}{*}{, $000^{*}$} \\
& Kütahya & 2,350 & 0,992 & & \\
Tourism Support & Afyonkarahisar & 4,245 & 0,679 & & \\
& Denizli & 3,971 & 0,699 & 47,318 & \multirow{2}{*}{, $000^{*}$} \\
& Kütahya & 3,601 & 0,901 & & \\
Perception of Life Quality & Afyonkarahisar & 3,897 & 0,626 & & \\
& Denizli & 3,740 & 0,879 & 59,443 &, $000^{*}$ \\
& Kütahya & 3,200 & 0,756 & & \\
\hline
\end{tabular}

Note. $\mathrm{p}<0,05$ there is a meaningful difference.

As it can be observed in Table 5, there are significant differences. The means regarding the variables in Table 6 indicate that the local people's perceptions on the economic and social effects of tourism are positive in all cities. Afyonkarahisar stands out among other provinces by having a very high average in terms of general negative perceptions of tourism, but also having a greater mean in terms of tourist support than other provinces. When considering the perception of quality of life, Kütahya has a slightly lower perception of quality of life compared to the other provinces. Post-hoc tests are required to determine the levels and significance of these differences, and these tests were carried out to obtain information on the specifics of the differences in this regard.

The homogeneity in the distribution of variances was considered when performing the Post Hoc tests. Levene statistics show positive economic perception $(p=.000)$, positive social perception $(p$ $=.000)$, negative perception $(\mathrm{p}=0.000)$, tourism support $(p=.002)$, and quality of life perception $(p=.000)$, also the variances are not homogeneously distributed. Accordingly, Tamhane statistics, which are recommended to be used for non-homogeneously distributed variances in Post Hoc tests, have been given in Table 7. 
Table 7. The Differences of Variables Within Provinces

\begin{tabular}{|c|c|c|c|c|c|c|}
\hline Dependent Variable & & Province (I) & Province $(\mathbf{J})$ & $\begin{array}{c}\text { Average Difference } \\
(I-J)\end{array}$ & S.D & Sig. \\
\hline \multirow[t]{3}{*}{ Perception of Life Quality } & Tamhane & Afyonkarahisar & Denizli &, $15628^{*}$ & ,06374 & ,038* \\
\hline & & & Kütahya &, $69661^{*}$ & 06673 &, $000 *$ \\
\hline & & Denizli & Kütahya &, $54033^{*}$ &, 06551 &, $000 *$ \\
\hline Positive Economic & Tamhane & Afyonkarahisar & Denizli &,$- 79072^{*}$ & ,06446 &, $000 *$ \\
\hline \multirow[t]{2}{*}{ Perception } & & & Kütahya &,$- 66872^{*}$ & 06449 &, $000 *$ \\
\hline & & Denizli & Kütahya &, 12200 & 05319 & 065 \\
\hline \multirow[t]{3}{*}{ Positive Social Perception } & Tamhane & Afyonkarahisar & Denizli &,$- 38258^{*}$ &, 05811 &, $000 *$ \\
\hline & & & Kütahya &,$- 22218^{*}$ & ,06317 &, $001 *$ \\
\hline & & Denizli & Kütahya &,$- 16040^{*}$ & 05715 &, $016^{*}$ \\
\hline \multirow[t]{3}{*}{ Tourism Support } & Tamhane & Afyonkarahisar & Denizli &, $27395^{*}$ & 05744 &, $000 *$ \\
\hline & & & Kütahya &, $64389^{*}$ & 07010 &, $000 *$ \\
\hline & & Denizli & Kütahya &, $36993^{*}$ & ,06986 &, $000 *$ \\
\hline \multirow[t]{3}{*}{ Negative Perception } & Tamhane & Afyonkarahisar & Denizli & $1,91818^{*}$ & 07549 &, $000 *$ \\
\hline & & & Kütahya & $1,82735^{*}$ & ,07903 &, $000 *$ \\
\hline & & Denizli & Kütahya &,- 09083 &, 07758 & ,471 \\
\hline
\end{tabular}

Note. $p<0,05$ there is a meaningful difference.

When Table 7 is examined, all three provinces have significant differences from each other in terms of quality-of-life perception. Afyonkarahisar province is seen to be differing significantly from Denizli, and Kütahya in terms of positive economic perception while there is no significant difference between Denizli, and Kütahya. Also, all three provinces differ in terms of positive social perception. Although there are significant differences between the perceptions of the local people living in the three provinces in terms of tourism support, it turns out that Afyonkarahisar differs from Denizli, and Kütahya in negative tourism perception, and there is no significant difference between Denizli, and Kütahya.

The relationship between the perception of quality-of-life and the other factors in terms of the provinces is given in Table 8 .

Table 8. Correlation of Quality-of-Life Perception and Other Factors by Provinces

\begin{tabular}{|c|c|c|c|c|}
\hline Item & & Perception & Quality & Sig \\
\hline \multirow{4}{*}{ Afyonkarahisar } & Positive Economic Perception & \multirow{4}{*}{ Correlation } &, $273 *$ &, 000 \\
\hline & Positive Social Perception & & $436 *$ &, 000 \\
\hline & Tourism Support & & $488^{*}$ & 000 \\
\hline & Negative Perception & &, $637 *$ & 000 \\
\hline \multirow{4}{*}{ Denizli } & Positive Economic Perception & \multirow{4}{*}{ Correlation } &, $224 *$ & 000 \\
\hline & Positive Social Perception & & $270 *$ & 000 \\
\hline & Tourism Support & & $234 *$ &, 000 \\
\hline & Negative Perception & &,- 015 & ,796 \\
\hline \multirow{4}{*}{ Kütahya } & Positive Economic Perception & \multirow{4}{*}{ Correlation } &,- 018 & ,780 \\
\hline & Positive Social Perception & &,- 021 & ,745 \\
\hline & Tourism Support & &, $195 *$ &, 002 \\
\hline & Negative Perception & &,- 032 & 616 \\
\hline
\end{tabular}

Note. $p<0,05$ there is a meaningful difference.

When the relationship between quality-of-life perception and the other variables of the research is analyzed according to the provinces, the relationship between Afyonkarahisar province participants' quality of life perceptions and positive economic perceptions are seen as (.273), positive social perceptions (.436), tourism support (.488) and negative perceptions as (.637) there is a significant and positive relationship. For the participants from Denizli province, there is a significant and positive relationship between the quality-of-life perceptions and positive economic 
perceptions (.224), positive social perceptions (.270) and tourism support (.234), but there is no significant relationship with the negative perception factor. Finally, when the results of Kütahya province are examined, a significant and positive relationship between the perception of quality of life and only the tourism support factor (.195) is found, while there is no significant relationship with the other factors.

\section{Conclusion and Suggestions}

A proper development of tourism in a destination is possible with the support of local people, who are the most important stakeholders of tourism because tourism is an event that takes place in a certain environment and the real inhabitants of this environment are the local people (Doğan \& Üngüren, 2010). Therefore, every change or development in the region has a direct effect on the local people. If the local people do not support tourism development, nothing can be achieved. For this reason, it becomes very important to determine the tourism perception and support of the local people in their own region and to know what the common sensitivities are.

In the current study, which was conducted in the provinces of Afyonkarahisar, Denizli, and Kütahya, the tourism perceptions of local people living in the thermal tourism regions of these provinces were determined in terms of different variables, with the goal of examining these differences and the socio-cultural and economic tourism perceptions of the local people, as well as their support for the development of tourism. According to the findings of the study, there are some differences in local people's perceptions of tourism based on province. Locals in Afyonkarahisar have a negative attitude toward tourism, whereas participants in Denizli, and Kütahya have the opposite attitude. The results regarding negative statements in Afyonkarahisar province are mostly thought to be stemming from the deterioration of traditions and morals. Still, the attitudes of local people towards tourism and support of them were found to be quite high when compared with Denizli, and Kütahya provinces. This result indicates that people in Afyonkarahisar have desire and support for the development of tourism despite the negative statements. In addition, all three provinces seem to be aware of the other opportunities that will be created and developed in the region together with tourism and these contribute to the positive perception of tourism. The obtained results are compatible with the studies by Akova (2006), Alaeddinoğlu (2007), Arıca and Ukav (2020), Bertan (2010), Doğan and Üngüren (2010), Duran and Özkul (2012), Hançer and Mancı (2017), Keskin and Çontu (2011), Özdemir and Kervankıran (2011), Sandal and Karademir (2016), Tayfun and Kıliçlar (2004), Uslu and Kiper (2006) and the data obtained from the scale used for the perception of the quality of life of the region where they live reveal that the quality-of-life perceptions of the local people living in the thermal tourism regions of Denizli, and Afyonkarahisar provinces are above the average. Although Kütahya province results are positive, they denote that the perception of quality of life is lower than the others. They also have a negative view especially about health and socio-cultural opportunities. When the results in the previous section are combined with these results, one of the most important factors in supporting the development of tourism by people living in Kütahya can be accepted as the contribution it will have to the development of their own living spaces.

The participants in the study have an overall satisfaction with their quality of life. It has been revealed that there are significant and positive relationships between the positive economic perception, positive social perception, negative perception, and tourism support variables of tourism and the perception of quality of life in Afyonkarahisar province, and there are significant 
and positive relationships in the variables other than the negative perception variable in Denizli. These results are consistent with the studies of Khizindar (2009), Kim (2002), Kim et al., (2013), and In Kütahya, there are only significant and positive relationships between the tourism support variable and the perception of quality of life. This result is also consistent with the results of the studies of Khizindar (2009), Türker et al., (2016).

The steady acceptance and support of tourism by the local people has a very important for part in the development of tourism in the regions. The results of the research also reveal that tourism support has a direct relationship with the perception of quality of life. Therefore, while the economic benefits of tourism and reducing its social negative effects play an important role in increasing local people's quality of life, this increase in the quality of life will also have a motivating effect on the support for the development of tourism and lead to a cycle of positive development.

\section{References}

Alaeddinoğlu, F. (2007). Van halkının turisti ve turizmi algılama şekli (Tourist profile and tourism perception stile of the people of Van). Cografi Bilimler Dergisi, 5(1), 1-16.

Akova, O. (2006). Yerel halkın turizmin etkilerini algılamalarına ve tutumlarına yönelik bir araştırma (Local people's impact of tourism on their perceptions and attitudes research). Akademik Incelemeler Dergisi, 1(2), 77-109.

Andereck, K.L., \& Vogt, C.A. (2000). The relationship between residents' attitudes toward tourism and tourism development options. Journal of Travel Research, 39(1), 27-36.

Andereck, K.L., Valentine, K.M., Knopf, R.C., \& Vogt, C.A. (2005). Residents' perceptions of community tourism impacts. Annals of Tourism Research, 32(4), 1056-1076.

Ap, J., \& Crompton, J. L. (1993). Residents' strategies for responding to tourism impacts. Journal of Travel Research, 32(1), 47-50.

Arıca, R. (2020). Seyahat acentalarında sürdürülebilir ürün üretimi ve yönetimi, Doğa temelli turların sistemleştirilmesi, Detay Yayıncılık.

Arıca, R. \& Ukav, İ. (2020). Effects of tourism development problems on tourist satisfaction and revisit intention: Example of Adiyaman. Journal of Tourism and Gastronomy Studies, 8(1), 371-387.

Bayat, G. (2010). Turizmin yerel halk tarafından algılanması: Iğdır halkı üzerine bir araştırma (Master Thesis). Kafkas Üniversitesi.

Bentler, P. M. (1980). Multivariate analysis with latent variables: Causal modeling. Annual Review of Psychology, $31,419-456$.

Bentler, P. M., \& Bonett, D. G. (1980). Significance tests and goodness of fit in the analysis of covariance structures. Psychological Bulletin, 88(3), 588-606.

Bertan, S. (2010). Pamukkale'deki yöre halkının turizmi desteklemesi ile turizmin sosyo-kültürel etkileri arasındaki ilişki (Relationship between tourism support and tourism impacts on socio-cultural in Pamukkale. International Journal of Economic and Administrative Studies, 2(4), 84-92.

Browne, M.W., \& Cudeck, R. (1993). Alternative ways of assessing model fit. In K. A. Bollen ve J. S. Long (Ed.), Testing structural equation models (pp. 136-162). Sage.

Büyüköztürk, Ş. (2016). Sosyal bilimler için veri analizi el kitabı. Pegem.

Cengiz, E., \& Kırkbir, F. (2007). Yerel halk tarafından algılanan toplam turizm etkisi ile turizm desteği arasındaki ilişkiye yönelik yapısal bir model önerisi (A Structural model suggestion about relationship between total tourism affect perceived by local residents and tourism support), Sosyal Bilimler Dergisi, 1, 19-37.

Choi, H.S.C., \& Sirakaya, E. (2005). Measuring residents' attitude toward sustainable tourism: Development of sustainable tourism attitude scale. Journal of Travel Research, 43(4), 380-394.

Coşkun, R., Altunışık, R., \& Yıldırım, E. (2017). Sosyal bilimlerde araştırma yöntemleri SPSS uygulamalı. Sakarya Yayınc1lik.

Çalışkan, U., \& Tütüncü, Ö. (2008, 23-27 Nisan). Turizmin yerel halk üzerindeki etkileri ve Kuşadası ilçesi uygulaması (The effects of tourism on local people and the application of Kuşadası district). IV. Lisansüstü Turizm Öğrencileri Araştırma Kongresi, Antalya. 
Çiçek, D., \& Sarı, Y. (2018). Yerel halkın turizme olan desteği: Türkiye'deki sakin şehirler üzerine bir araştırma. (Local resident's tourism support: A study on slow cities in Turkey). Anatolia: Turizm Araştırmalart Dergisi, 29(2), 185-196.

Davis, D., Allen, J., \& Cosenza, R. M. (1988). Segmenting local residents by their attitudes, interests, and opinions toward tourism. Journal of Travel Research, 27(2), 2-8.

Doğan, H., \& Üngüren, E. (2010). Alanya halkının turizme sosyo kültürel açıdan bakışı (Perception of Alanya community for the socio- cultural effects of tourism), e-Journal of New World Sciences Academy, 5(4), 396-415.

Duran, E., \& Özkul, E. (2012). Yerel halkın turizm gelişimine yönelik tutumları: Akçakoca örneği üzerinden bir yapısal model (Residents' attitudes toward tourism development: A structural model via Akçakoca sample) International Journal of Human Sciences, 9(2), 500-520.

Dwyer, L., Forsyth, P., Fredline, L., Jago, L., Deery, M., \& Lundie, S. (2006). Concepts of tourism yield and their measurement. CRC for Sustainable Tourism. Sustain. http://sustain.pata.org/wpcontent/uploads/2014/12/Dwyer_Tourism-Yield.pdf,

Ekici, R., \& Çizel, B. (2014). Yerel halkın turizm gelişimi desteğine iliş̧in tutumlarının destinasyonların gelişme düzeylerine göre farklılıkları (Differences in resident's attitudes toward supporting tourism development according to the development level of destinations. Seyahat ve Otel İsletmeciliği Dergisi, 11(3). 73-88.

Epley, D. R., \& Menon, M. (2008). A method of assembling cross-sectional Indicators into a community quality of Life. Social Indicators Research, 88(2), 281-296.

Farrell, B., \& Twining-Ward, L. (2005). Seven steps towards sustainability: Tourism in the context of new knowledge. Journal of Sustainable Tourism, 13(2), 109-122.

Getz, D. (1987). Tourism planning and research: Traditions, models and futures. In Proceedings of the Australian Travel Workshop, Australian Travel Workshop.

George, D., \& Mallery, M. (2010). SPSS for windows step by step: A simple guide and reference, 17.0 update (Tenth edition) Pearson.

Graburn, N. H., \& Jafari, J. (1991). Introduction: tourism social science. Annals of Tourism Research, 18, 1-11.

Gökmen, Ç. E., (2018). Turizm sektöründe göçmen emeği: Nitelikli emek mi? Ucuz Emek mi? (Migrant Labor in Tourism Sector: Is it Qualified Labor? Or Cheap Labor?,) Çalışma ve Toplum, 56(1), 139-166.

Gunn, C. A. (1988). Tourism Planning, Taylor \& Francis.

Gürsoy, D., \& Rutherford, D. G. (2004). Host attitudes toward tourism: An improved structural model, Annals of Tourism Research, 31(3), 495-516.

Hançer, Ş., \& Mancı, A. R. (2017). Yerel halkın turizme bakış açısının belirlenmesi üzerine bir araştırma: Diyarbakır örneği. (A Research on the determination of residents' perception about tourism in Diyarbakır). Journal of Tourism and Gastronomy Studies, 5(4), 70-91.

Hardy, A., Beeton, R. J., \& Pearson, L. (2002). Sustainable tourism: An overview of the concept and its position in relation to conceptualisations of tourism. Journal of Sustainable Tourism, 10(6), 475-496.

Jaafar, M., Noor, S. M., \& Rasoolimanesh, S. M. (2015). Perception of young local residents toward sustainable conservation programmes: A case study of the Lenggong world cultural heritage site. Tourism Management, 48, 154-163.

Jafari, J. (2003). Research and scholarship the basis of tourism education. The Journal of Tourism Studies, 14(1), 616.

Jurowski, C., Uysal, M., \&Williams, R.D. (1997). A theoretical analysis of host community resident attractions to tourism. Journal of Travel Research, 36(2), 3-11.

Karakaş, A., \& Şengün, H. İ. (2016). Yerel halkın turizm faaliyetlerine yönelik tutumları (Local people's attitudes toward tourism activities), Bartın Üniversitesi İktisadi ve İdari Bilimler Dergisi. 8(15), 183-202.

Keogh, B. (1990). Public participation in community tourism planning. Annals of Tourism Research, 17(3), 449465.

Keskin, E., \& Çontu, M. (2011). Mustafapaşa (Sinasos) kasabasında yaşayan halkın turizme bakış açısını belirlemeye yönelik bir alan araştırması (A field study of determining Mustafapaşa (Sinasos) Inhabitants' opinion on tourism), Aksaray Üniversitesi IIIBF Dergisi, 3(2), 37-55.

Khizindar, T. M. (2009). Quality of life in developing countries: An empirical investigation. Journal of American Academy of Business, 14(2), 162-170.

Kim, K. (2002). The effects of tourism impacts upon quality of life of residents in the community (PhD dissertation). Virginia Polytechnic Institute and State University.

Kim, K., Uysal, M., \& Sirgy, M. J. (2013). How does tourism in a community impact the quality of life of community residents? Tourism Management, 36, 527-540. 
Ko, D. W., \& Stewart, W. P. (2002). A structural equation model of residents 'attitudes for tourism development. Tourism Management, 23(5), 521-530.

Malek, A., \& Costa, C. (2015). Integrating communities into tourism planning through social innovation. Tourism Planning \& Development, 12(3), 281-299.

Marsh H.W., \& Hocevar D. (1985). Application of confirmatory factor analysis to the study of self-concept: firstand higher order factor models and their invariance across groups. Psychological Bulletin. 97(3), 562-582.

McGehee, N. G., \& Andereck, K. L. (2004). Factors predicting rural residents' support of tourism. Journal of Travel Research, 43(November), 131-140.

Murphy, P. E. (1983). Tourism as a community industry an ecological model of tourism development. Tourism Management, 4(3), 180-193.

Özdemir, M. A., \& Kervankıran, İ. (2011). Turizm ve turizmin etkileri konusunda yerel halkın yaklaşımlarının belirlenmesi: Afyonkarahisar Örneği, (Determining the attitudes of local people towards tourism and its effects: A case study from Afyonkarahisar), Marmara Coğrafya Dergisi, 24, 1-25.

Özmen, M. (2007). Turizmin sosyo-kültürel etkileri: Akçakoca örneği (Social and cultural impacts of tourism: An application in Akçakoca) (Yüksek Lisans Tezi). Abant İzzet Baysal Üniversitesi Sosyal Bilimler Enstitüsü.

Pelit, E., Baytok, A., \& Soybalı, H. H. (2015). Sürdürülebilir turizm mi? Turizmde sürdürülebilirlik mi? Kavramsal bir tartışma (Sustainable Tourism? Or Sustainability in Tourism? A conceptual Discussion), Gümüşhane Üniversitesi Sosyal Bilimler Enstitüsü Elektronik Dergisi, 6(14), 39-58.

Perdue, R.R., Long, P.T., \& Allen, L. (1990). Resident support for tourism development. Annals of Tourism Research, 17(4), 586-599.

Prentice, R. (1993). Community-driven tourism planning and residents' preferences. Tourism Management, 14(3), 218-227.

Rahtz, D.R., \& Sirgy, M.J. (2000). Marketing of health care within a community: A quality-of-life/needs assessment model and method. Journal of Business Research, 48(3), 165-176.

Rasoolimanesh, S. M., Jaafar, M., Kock, N., \& Ramayah, T. (2015). A revised framework of social exchange theory to investigate the factors influencing residents' perceptions. Tourism Management Perspectives, 16, 335 345.

Sandal, E. K., \& Karademir, N. (2016). Kahramanmaraş’ta halkın turizme bakışı (Public view about tourism in Kahramanmaraş), Türk Coğrafya Dergisi, 66, 63-70.

Suess, C., Baloglu, S., \& Busser, J. A. (2018). Perceived impacts of medical tourism development on community wellbeing. Tourism Management, 69, 232-245.

Tanrisevdi, A., Ozdogan, O., Acar, V., \& Kilicdere, S. (2021). Destination management: Right or wrong measures. Journal of Global Business Insights, 6(1), 1-21.

Tayfun, A., \& Kılıçlar A. (2004). Turizmin sosyal etkileri ve yerli halkın turiste bakışı (Social implications of tourism and host community's perception of tourism), Gazi Üniversitesi Ticaret ve Turizm Fakültesi Dergisi, (1), 1-17.

Theuns, H. L. (2002). Tourism and development: Economic dimensions. Tourism Recreation Research, 27(1), 6981.

Timothy, D. J. (1999). Participatory planning: A view of tourism in Indonesia. Annals of Tourism Research, 26(2), 371-391.

Tosun, C. (2000). Limits to community participation in the tourism development process in developing countries. Tourism management, 21(6), 613-633.

Tosun, C. (2002). Host perceptions of impacts: A comparative tourism study. Annals of Tourism Research, 29(1), 231-253.

Türker, N., Selçuk, Ş., \& Özyıldırım, A. (2016). Turizmin yerel halkın yaşam kalitesi üzerine etkisi: Safranbolu Örneği (The Effect of Tourism in Residents' Quality of Life: The Case of Safranbolu), Karabük Üniversitesi Sosyal Bilimler Enstitüsü Dergisi, 6(1), 1-13.

Uslu, A., \& Kiper, T., (2006). Turizmin kültürel miras üzerine etkileri: Beypazarı/Ankara örneğinde yerel halkın farkındalığı (Effects of tourism on cultural heritage: Awareness of local people in Beypazarı, Ankara), Tekirdă̆ Ziraat Fakültesi Dergisi, 3(3), 305-314.

Ünlüönen, K., \& Özekici, Y. K. (2017). Yeni gelişen destinasyonlarda turizm algısı: Yozgat ili üzerine bir alan araştırması (Tourism perception in emerged destinations: A field study on Yozgat), Journal of Tourism and Gastronomy Studies, 5(4), 466-488.

Vatan, A., \& Zengin, B. (2015). Söğüt ilçesi’nde kültürel miras ve yerel halkın turizme bakış açısı (Cultural heritage in Söğüt and perspective of local public about tourism), Akademik Sosyal Araştırmalar Dergisi, (10), 634650. 